April 2007

\title{
Halting Genocide: Rhetoric versus Reality
}

Thomas G. Weiss

Follow this and additional works at: https://digitalcommons.usf.edu/gsp

\section{Recommended Citation}

Weiss, Thomas G. (2007) "Halting Genocide: Rhetoric versus Reality," Genocide Studies and Prevention: An International Journal: Vol. 2: Iss. 1: Article 3.

Available at: https://digitalcommons.usf.edu/gsp/vol2/iss1/3

This Articles is brought to you for free and open access by the Open Access Journals at Digital Commons @ University of South Florida. It has been accepted for inclusion in Genocide Studies and Prevention: An International Journal by an authorized editor of Digital Commons @ University of South Florida. For more information, please contact digitalcommons@usf.edu. 


\title{
Halting Genocide: Rhetoric versus Reality
}

\author{
Thomas G. Weiss \\ Presidential Professor of Political Science and Director of the \\ Ralph Bunche Institute for International Studies, The Graduate \\ Center of The City University of New York
}

\begin{abstract}
The chasm between normative development and international practice regarding humanitarian intervention is wide, as evidenced by the ongoing genocide in Darfur. Rarely are political reality and pious rhetoric in sync. Depicting the normative development on a graph would reflect a steady growth since the early 1990s, whereas the curve depicting the operational capacity and political will to engage in humanitarian intervention would resemble the path of a roller coaster. This article examines the trajectory of norm building about military intervention for human protection purposes, emphasizing the concept of the "responsibility to protect." While considerable progress has been made toward resolving the fundamental tension between the principles of state sovereignty and human rights, the actual practice of military humanitarianism has reached a nadir at present. The article highlights five impediments to human protection in genocidal contexts: the resistance from the Non-Aligned Movement; the blowback from 9/11; a distracted superpower; spoilers, war economies, and privatization; and the civilian humanitarian identity crisis itself.
\end{abstract}

In the midst of the 1994 genocide in Rwanda, the world's powers cloaked their non-reactions in a semantic fog about "genocide." Their refusal to invoke the term provided an excuse for standing idle in the face of mass murder. A decade later, the US House of Representatives followed the lead of Secretary of State Colin Powell and voted unanimously to label as genocide the killings and forced migration in Darfur. The use of the term for Khartoum's actions, however, triggered a collective yawn and did nothing to protect those under siege from Sudanese government troops and the Janjaweed. Thus, except for the label, the responses by the international community of states to Rwanda and Sudan were comparable. Perhaps, as Scott Straus has argued in these pages, ${ }^{1}$ we have invested too much time and energy in parsing the "G-word."

Not only has military action for human protection faltered, but civilian humanitarians are also in the midst of an "identity crisis." The changing nature of warfare has challenged their traditional operating principles; indeed, old modes have had un-humanitarian consequences, particularly in the context of the "new wars." Aid agencies fed the killers who had perpetrated the Rwandan genocide but had then moved to refugee camps located in then Zaïre, thereby facilitating further acts of violence-just one example of David Kennedy's "dark sides of virtue."2

This article explores the chasm between norms and practice for both military and civilian humanitarians. The increased support for an international responsibility to protect (R2P), as evident in the approval by the September 2005 World Summit, ${ }^{3}$ confronts the atrocities in Sudan, northern Uganda, and the Democratic Republic of the Congo (DRC). While states have failed to provide military resources to protect those caught in the crossfire of war, aid agencies have

Thomas G. Weiss, "Halting Genocide: Rhetoric versus Reality." Genocide Studies and Prevention 2, 1 (April 2007): 7-30. (C) 2007 Genocide Studies and Prevention. 
struggled to adapt to contemporary wars, but with little evidence of effective learning about modifying the humanitarian impulse to "do no harm." The article also examines five impediments to human protection in genocidal contexts: resistance from the Non-Aligned Movement (NAM); the blowback from 9/11; a distracted superpower; spoilers, war economies, and privatization; and the civilian humanitarian identity crisis itself.

\section{Military Humanitarianism: Normative Progress}

A remarkable development of the post-Cold War era has been the use of military force to protect human beings trapped in the throes of war. With the possible exception of the 1948 Convention on the Prevention and Punishment of the Crime of Genocide (UNCG) ${ }^{4}$ no normative idea has moved faster in the international arena than The Responsibility to Protect, the 2001 report of the International Commission on Intervention and State Sovereignty (ICISS). ${ }^{5}$ At the same time, the inability to protect many besieged populations starkly highlights the dramatic disconnect between political reality and pious rhetoric.

Indeed, the two are rarely in sync. Sometimes norm entrepreneurs scramble to keep up with political reality, and sometimes they are ahead of the curve. In this case, depicting normative development on a graph would reflect a steady growth since the early 1990s, whereas the curve depicting the operational capacity and political will to engage in humanitarian intervention would resemble the path of a roller coaster. Hence, the US-led and UN-approved intervention in northern Iraq in 1991 took place largely without any formal discussion of moral justifications. In spite of continual fireworks in debates about international responses to conscience-shocking events, from Central Africa to the Balkans, the World Summit on the United Nations' sixtieth anniversary represented the zenith of international normative consensus about R2P. At the same time, the blowback from 9/11 and the war on terror and in Iraq resulted in a nadir in the actual practice of humanitarian intervention.

\section{Sovereignty as Responsibility and Kofi Annan's "Two Sovereignties"}

Two intellectual efforts prior to convening the ICISS broke new ground between state sovereignty and human rights and provided the underpinnings of The Responsibility to Protect. First was the normative work of Francis M. Deng and Roberta Cohen on the issue of internally displaced persons (IDPs), which directly confronted the behavior of states toward their own citizens. Second was UN Secretary-General Kofi Annan's activism on behalf of human rights and his efforts to promote individual alongside state sovereignty.

Concerned to protect IDPs as an ever-increasing category of war victim, Deng and Cohen reframed sovereignty. First articulated in the 1980s, their "sovereignty as responsibility" stipulated that when states are unable to provide life-supporting protection and assistance for their citizens, they are expected to request and accept outside offers of aid. ${ }^{6}$ Should they refuse or deliberately obstruct access to their displaced or other affected populations and thereby put large numbers of them at risk, there is an international responsibility to respond. Sovereignty entails accountability to two separate constituencies: internally to one's own population and internationally to the community of responsible states in the form of compliance with human-rights and humanitarian agreements. Proponents argue that sovereignty is not absolute but 
contingent. When a government massively abuses the fundamental rights of its citizens, its sovereignty is temporarily suspended.

The second key intellectual contribution came from Secretary-General Kofi Annan, who, more than his predecessors, took human rights seriously and preached sermons about humanitarian intervention from his bully pulpit. With the help of his scribe, Edward Mortimer, a series of speeches in 1998 and 1999 placed the issue squarely on the intergovernmental agenda. ${ }^{7}$

Annan's black-and-white challenge to traditional state sovereignty reflects a change in the balance between states and people as the source of legitimacy and authority. Like Deng and Cohen, Annan sought to broaden the concept of sovereignty to encompass both the rights and the responsibilities of states. The secretary-general's clarion call was hard to muffle, especially after The Economist published his "two concepts of sovereignty" in September 1999:

State sovereignty, in its most basic sense, is being redefined... States are now widely understood to be instruments at the service of their peoples, and not vice versa ... When we read the Charter today, we are more than ever conscious that its aim is to protect individual human beings, not to protect those who abuse them. ${ }^{8}$

Later that week, in his opening address to the General Assembly, the future Nobel laureate's moral plea reached all member states in six official UN languages, ${ }^{9}$ and the same theme was put forward more delicately a year later at the Millennium Summit. ${ }^{10}$

The reactions in the General Assembly hall were raucous and predictable, from China, Russia, and, especially, much of the Third World. Unilateral intervention-that is, without Security Council authorization, however many countries are involved in a coalition-for whatever reasons, including genuine humanitarian ones, remains taboo. As Gareth Evans tells us, "sovereignty thus hard won, and proudly enjoyed, is sovereignty not easily relinquished or compromised."11

Annan's reframing helped shift the balance away from the absolute rights of state leaders to respect for the popular will and internal forms of governance based on international standards. ${ }^{12}$ Advocates suggest that the sovereignty of a state does not stand higher than the human rights of its inhabitants. That this argument came from the world's top international civil servant resonated loudly.

\section{The Responsibility to Protect}

The ICISS mandate was to build on this emerging understanding of the problem of intervention and state sovereignty and to find political consensus on military intervention to support humanitarian objectives. The immediate stimuli were the divergent reactions-or rather, non-reactions-by the Security Council to Rwanda and Kosovo. In 1994 intervention was too little and too late to halt, or even slow, the murder of what may have been as many as 800,000 people in the Great Lakes region of Africa. In 1999 the formidable North Atlantic Treaty Organization (NATO) finessed the council and waged war, for the first time in its fifty years of existence, in Kosovo. But many observers saw the seventy-eight-day bombing effort as too much and too early, perhaps creating as much suffering as it relieved. In both cases, the Security Council failed to act expeditiously to protect vulnerable populations.

The ICISS laid down two normative markers. First, it aimed to alter the consensus on the use of deadly force to help victims in harm's way. Second, it emphasized that the international responsibility to intervene to halt mass killings and ethnic cleansing is located with the Security Council, and that any intervention should be efficient and effective. 
The "basic principles" merit attention:

A State sovereignty implies responsibility, and the primary responsibility for the protection of its people lies with the state itself.

B Where a population is suffering serious harm as a result of internal war, insurgency, repression, or state failure, and the state in question is unwilling or unable to halt or avert it, the principle of non-intervention yields to the international responsibility to protect. $^{13}$

The recognized need to reinforce state capacity is not a misplaced nostalgia for repressive regimes but, rather, an apt recognition, even among committed advocates of human rights and robust intervention, that state authority is fundamental to enduring peace and reconciliation. Human rights can be defended over the longer term only by democratic states with the authority and the monopoly of force to sustain such norms. The responsibility to protect embraces a temporal continuum-before, during, and after assaults on civilians. Clearly, preventing the outbreak of mass violence would be preferable to intervening to stop it, and commitments to postconflict peace building also are imperative if the long-term benefits of intervention are to be realized.

The challenges before and after the outbreak of lethal conflicts are indisputable, but more urgent still is non-consensual intervention to protect populations under deliberate attack. Whether or not states will act to prevent armed conflict or be in a position to commit themselves to longer-run investments, should we throw up our hands and forget taking feasible steps to stop mass murder?

For bullish humanitarians, any loss of life is appalling. For the ICISS, which accurately reflects the existing international political consensus on the subject, a higher threshold of human suffering must be crossed: acts of such a magnitude that they shock the conscience and elicit a fundamental humanitarian impulse.

Intervention consists of three categories of threat or actual use of coercion: military force, economic sanctions and arms embargoes, and international criminal prosecution. While "military intervention for human protection purposes is an exceptional and extraordinary measure," the ICISS report specifies what warrants such. ${ }^{14}$ The "just cause threshold" is reached if the following conscience-shocking harms occur:

A large scale loss of life, actual or apprehended, with genocidal intent or not, which is the product either of deliberate state action, or state neglect or inability to act, or a failed state situation; or

B large scale "ethnic cleansing," actual or apprehended, whether carried out by killing, forced expulsion, acts of terror or rape. ${ }^{15}$

This double-barreled justification does not go as far as many would have hoped. However, the insertion of "actual or apprehended" to qualify both agreed thresholds opens the door fairly wide to acting in advance of massive loss of life or forced displacement. Justifiable causes could include the overthrow of a democracy or violations of human rights. The requirement to endure high levels of loss of life before any action would have undermined the logic of saving lives.

St. Thomas Aquinas or the contemporary moral voices of Michael Walzer and Bryan Hehir ${ }^{16}$ would undoubtedly be pleased by the "precautionary principles" behind the responsibility to protect. The debate in the $1990 \mathrm{~s}$ can be seen as moving beyond whether to intervene to how. ${ }^{17}$ The ICISS's modified just-war doctrine includes four elements: right intention, last resort, proportional means, and reasonable prospects. 
Since the Security Council's lack of reaction to Rwanda and inability to act in Kosovo were the commission's main driving force, the question of "right authority" was critical. The ICISS report emphasizes that "there is no better or more appropriate body than the United Nations Security Council to authorise military intervention for human protection purposes."18 At the same time, the commission left open the possibility -indeed, the necessity—that "if it fails to discharge its responsibility to protect in conscience-shocking situations crying out for action, concerned states may not rule out other means to meet the gravity and urgency of that situation and that the stature and credibility of the United Nations may suffer thereby." 19 This possibility reflects the bottom line of the Kosovo Commission: "the NATO military intervention was illegal but legitimate." 20

The elegant vacillation revolves around the question, What if? Of course, the reputation of the United Nations will suffer; and states will and should not rule out other means to react. The intrinsic reality remains the same as it has been throughout the Westphalian era: if there is a political will and an operational capacity, humanitarian or other interventions will happen. ${ }^{21}$

The ICISS process has had two results. First, it reformulates the conceptual basis for humanitarian intervention. It calls for moving away from the rights of interveners toward the rights of victims and the responsibilities of outsiders to act. It is primarily state authorities whose citizens are threatened who have the responsibility to protect. Yet a residual obligation rests with the larger community of states when an aberrant member of their club misbehaves egregiously, or implodes. The status of state sovereignty is not challenged, per se, but reinforced. However, if a state is unwilling or unable to exercise its protective responsibilities for the rights of its own citizens, it forfeits the moral claim to be treated as legitimate. Its sovereignty, as well as its right to non-intervention, is suspended; and the residual responsibility necessitates vigorous action by outsiders to protect populations at risk. Essentially, governments not intervening in the face of massive loss of life and displacement should be embarrassed.

Second, the ICISS proposes a new international default setting-a modified justwar doctrine for future interventions to sustain humanitarian values or human rights. The Security Council was largely missing in action during the Cold War. In the 1970s and 1980s, "the Security Council gave humanitarian aspects of armed conflict limited priority ... but the early nineteen-nineties can be seen as a watershed." 22 During the first half of the decade, twice as many resolutions were passed as during the first fortyfive years of UN history. These resolutions contain repeated references, in the context of chapter 7, to humanitarian crises amounting to threats to international peace and security and repeated demands for parties to respect the principles of international humanitarian law.

Optimists view the ICISS's The Responsibility to Protect as the most comprehensive attempt to date to tackle the question of sovereignty versus intervention, and even bitter opponents such as Mohammed Ayoob admit its "considerable moral force." 23 The endorsement of more than 150 presidents, prime ministers, and princes at the 2005 World Summit demonstrates normative consensus. Indeed, R2P was one of the few substantive items to emerge relatively intact from the negotiations at the summit. ${ }^{24}$ The final outcome document contained an unambiguous acceptance of individual state responsibility to protect populations from genocide, war crimes, ethnic cleansing, and crimes against humanity.

However, the summit's language could also be seen as a step backward, or "R2P lite," for two reasons. ${ }^{25}$ First, humanitarian intervention has to be approved by the 
Security Council, and the document makes no mention of "what if?" Second, the overemphasis on state responsibility and the absence of an "international" responsibility to protect permits continued foot-dragging in places like Darfur. In addition, the World Summit also kicked the issue of criteria back to the General Assembly, where a discussion is bound to stall.

However, the overall treatment of R2P suggests that consensus building can sometimes take place around even the most controversial issues and with opposition from the strangest of bedfellows - in this case, the United States and the Non-Aligned Movement. The summit's final text reaffirms the primary roles of states in protecting their own citizens and encourages international assistance to weak states to exercise this responsibility. At the same time, it also makes clear the requirement for international intervention when countries fail to shield their citizens from (or, more likely, actively sponsor) genocide.

\section{Military Humanitarianism: On-the-Ground Realities}

Normative developments are promising, but on-the-ground humanitarian intervention, or, rather, the lack thereof, is cause for cynicism. Overzealous military action for insufficient humanitarian reasons-long the battle cry in the global South-certainly is no danger. Rather, the real threat to international society comes from doing nothing while condoning massive suffering in the DRC, overlooking slaughter in northern Uganda, and observing Sudan's slow-motion genocide.

Indeed, the conflict in the DRC, often described as "Africa's First World War," is the deadliest on the planet since World War II. The simultaneous domestic and international conflict-directly involving nine African countries and some twenty armed groups-is fueled by the looting of rich deposits of copper, zinc, and diamonds as well as by ethnic violence and tribal warfare. ${ }^{26}$ Since 1998 , an estimated 4 million people have died, largely from the famine and disease accompanying armed conflict.

The United Nations' foray into the war-torn country began in 1999, after a tenuous brokered peace agreement. Although considerably expanded from its original deployment, the UN Mission in the Democratic Republic of the Congo, authorized under chapter 7 of the UN Charter, consists of a mere 15,900 troops, well below the secretary-general's suggested troop level of 23,900 to secure peace and security in a country the size of Western Europe. ${ }^{27}$ The relative success, for the moment, of two sets of elections in 2006 does not contradict the total absence of political will to address the world's most "forgotten emergency," ${ }^{28}$ the numerical equivalent of five Rwandas.

If the DRC is forgotten, the situation in northern Uganda amounts to a "secret genocide," according to Olara Otunnu, the former UN under-secretary-general and special representative for children and armed conflict. ${ }^{29}$ Although Uganda's President Yoweri Museveni is generally hailed in the media and by international financial institutions as a new model for Africa, the decade-long effort to subjugate some 2 million people (from the Acholi, Lango, and Teso regions) in 200 refugee camps is a hidden side of Museveni's "success." Ninety-five percent of the Acholi live in these camps, where as many as 1,500 children die each week and the rate of HIV infection may be $50 \%$. "The genocide in northern Uganda is a burning test for the United Nations' declaration on the 'Responsibility to Protect," writes Otunnu. "Urgent action is essential to save them-and redeem the international community's promise."30

Meanwhile, in Sudan, a kind of international "activism" is present. Firm numbers are hard to come by concerning the catastrophe in Darfur; at least 200,000 but as many as 400,000 black Africans may have died, countless women left behind have been 
raped, and as many as 3 million people have been forcibly displaced. The collective spinelessness since early 2003 in the face of Darfur's disaster could be even more destructive of the fabric of international law than the 800,000 deaths in Rwanda. At least, in 1994, the Clinton administration attempted to maintain the fiction that no such horror was under way as would have implied the necessity to act. ${ }^{31}$ But no longer can we put that genie back in the bottle. If we recognize genocide and do nothing, the 1948 UNCG literally is not worth the paper on which it is reproduced.

This time the facts are not disputed. New York Times columnist Nicholas Kristof has conscientiously called attention to the tragedy but cryptically lamented that "the publishing industry manages to respond more quickly to genocide than the UN and world leaders do." ${ }^{2}$ The US Congress condemned Darfur unanimously, voting 422-0 in July 2004 that Khartoum was committing "genocide,"33 and Secretary of State Colin Powell used the dreaded term in a speech in September of that year, ${ }^{34}$ which coincided with views from such private groups as Physicians for Human Rights. ${ }^{35}$ In the same month, European Union parliamentarians urged Sudan to end actions that could be "construed as tantamount to genocide." 36

Rather than military action to halt the killing and displacement, the reinforced Third World apprehension about any Western pressure in the hapless Sudan led to the deployment of 7,000 largely ineffective African Union (AU) soldiers and an investigation by the International Criminal Court. ${ }^{37}$ In February 2006, the Security Council decided to absorb the AU troops into a UN force that could number between 12,000 and 20,000 when and if it were deployed. Three years after the killing and displacement began, it remained unclear which countries (other than the United States, which categorically said "no") would put boots on the ground. In April 2006, when the council managed only to agree on targeted sanctions against four individuals, the chasm between the magnitude of the suffering and the international response could hardly have been greater.

The charade continued throughout the summer and fall as states slavishly courted the central government to seek its permission before sending more troops. Khartoum, responsible for the tragedy in the first place, expelled the outspoken special representative Jan Pronk in October 2006. The UN's point man for humanitarian affairs, Jan Egeland, asserted that "we are playing with a powder keg." 38 In addition to the mass killing and displacement, continued insecurity left some one million people beyond the reach of aid workers, rendering them vulnerable to starvation and disease. Even if, eventually, the feeble AU force is reinforced with UN-mandated soldiers and the problems of such a mixed force are overcome, the result will have been another ugly scar on the international record.

Khartoum cleverly linked even feeble Western activism in Darfur to US and British action in Iraq. As David Rieff writes, "in Europe or the U.S., sending NATO forces to Darfur may seem like fulfilling the global moral responsibility to protect. But in much of the Muslim world, it is far likelier to be experienced as one more incursion of a Christian army into an Islamic land."39

Specific military challenges in giving operational meaning to R2P are distinct from the more familiar ones of either peacekeeping or fighting a war, the end points on a spectrum of international military action. The ICISS research volume sought especially to highlight specific challenges in between-namely, how protection can be afforded to populations at risk, and how those who prey upon them can be deterred. $^{40}$ 
To date, the cumulative scorecard is discouraging for meeting the challenges of coercive protection, which potentially is politically and militarily less onerous than compelling compliance. A recent Stimson Center report demonstrates that precious little has changed in the half-decade since the publication of the ICISS volumes. Western militaries have not moved to develop the key concepts-for example, what it would take to establish a no-fly zone over Darfur and Chad, or to disarm a refugee camp, or to protect a safe area. The absence of political will by major powers is clearly an obstacle to military deployments to protect war victims, but so too is the lack of evolution in military doctrine. Some even question whether the protection of civilians is an impossible mandate. Deployed forces often lack the operational guidance and military preparation to effectively intervene to halt genocide and shield civilians from heinous abuses. Victoria Holt and Tobias Berkman argue that "the time has come to translate the 'responsibility to protect' into terms that militaries can understand and implement-such as concepts of operation, doctrine, training, rules of engagement, and mandates-to move lofty ideals into concrete actions on the ground." 41

\section{Civilian Humanitarianism: Contesting Standard Principles and Operating Procedures}

The treacherous and unfamiliar terrain of Mary Kaldor's "new wars"-internal armed conflicts waged primarily by non-state actors who subsist on illicit and parasitic economic behavior, use small arms and other low-technology hardware, and prey upon civilians, including aid workers and journalists-has created substantial challenges for civilian humanitarians. While debate rages about how "new" many elements of contemporary wars are-that is, many of the same elements have been present in the past - the intensity and magnitude at least constitute the equivalent of dramatically new contexts that call into question humanitarian strategies and tactics from earlier wars.

In a famous desiderata, Jean Pictet of the International Committee of the Red Cross (ICRC) identified seven core principles: humanity, impartiality, neutrality, independence, voluntary service, unity, and universality. ${ }^{42}$ The first four principles, though, arguably constitute the core of the "off-the-rack humanitarian suit." 43 Humanity commands attention to all people. Impartiality demands that assistance be based solely on need, without discrimination among recipients because of nationality, race, religion, or other social characteristics: if necessary, aid agencies should be prepared to provide assistance to all sides of a conflict. Neutrality, like impartiality, involves refraining from taking part in hostilities and from any action that knowingly either benefits or disadvantages the parties to an armed conflict. Neutrality is both an end and a means because it helps relief agencies gain access to populations at risk. Independence demands that aid not be connected to any of the parties directly involved in the conflict or having a stake in the outcome, including donors who fund particular activities.

If war-related international humanitarianism had an inaugural moment, it was the ICRC's 1864 establishment and the emergence of international humanitarian law. ${ }^{44}$ In response to the circumstances of fallen and injured soldiers, humanitarian activists pursued an immediate goal-to convince states to give them access to these populations at risk. The popularity and resonance of the idea were enormous; within three years the grassroots campaign produced the ICRC and the Geneva Conventions.

Humanitarianism's next great leap forward occurred as a consequence of the two world wars of the twentieth century. In terms of institution building, many of the most 
familiar of today's non-governmental and intergovernmental organizations emerged in reaction to the forces of destruction. NGOs, in most cases, were running ahead of states in the area of refugee relief (and lobbying states to do their share).

World War II proved to be a moment when the very specter of rampant inhumanity led an "international community" to create a hope for a different future. The Holocaust, the death camps, the death marches, the fire bombings, and the use of nuclear weapons led diplomats and activists to call for protecting civilians, the dispossessed, and human dignity. The very idea of human dignity led to such normative humanitarian pillars as the 1945 UN Charter, the 1948 Universal Declaration of Human Rights, the UNCG, and the 1949 Geneva Conventions (and, eventually, the 1977 Additional Protocols). More intergovernmental and non-governmental machinery resulted.

During the Cold War, the Security Council defined "threats to international peace and security" as disputes between states that might or had become militarized, conflicts involving the great powers, and general threats to global stability. After the Cold War-and in reaction to the growing perception that domestic conflict and civil wars were leaving hundreds of thousands of populations at risk, creating mass flight, and destabilizing entire regions-the council authorized interventions where war-induced disasters imperiled regional and international security.

Although academic debate continued about whether the dynamics of such warfare were new, the significance of "new wars" was obvious on the international agenda and in the media spotlight. ${ }^{45}$ A new label, "complex humanitarian emergencies," depicted the ugly and confusing reality of a "conflict-related humanitarian disaster involving a high degree of breakdown and social dislocation and, reflecting this condition, requiring a system-wide aid response from the international community." 46

In a world in which armed conflict was largely of the interstate variety, the ICRC's principles made sense-indeed, they constituted a "gold standard." Belligerents were states confined by international law, which placed limits on how they waged war. The Geneva Conventions outlawed attacks on civilians and guaranteed access to those seeking to help injured soldiers and populations at risk. State adherence to constraints on war was motivated not by altruism but, rather, by the reciprocal interests of warring state parties. Clearly, today's landscape is different.

\section{Civilian Humanitarianism: New Humanitarian Conundrums}

Contemporary warfare is mainly intrastate, with warring parties who operate without constraints. Violence against civilians has indeed become a staple tactic of warfare. In Rwanda some 800,000 people (one-tenth of the population) were slaughtered in a period of a few weeks, while as many as 250,000 to 500,000 women were raped and half the population forcibly displaced; and in Bosnia-Herzegovina there were some 250,000 deaths, with between 20,000 and 50,000 rapes, and 2.7 million people in need of assistance. Such disasters pose significant quantitative and qualitative challenges for those seeking to come to the rescue.

The plethora of civil wars in the 1990s, usually characterized by large-scale killing and displacement, challenged the traditional operating principles of humanitarians. Anxiety and doubt arose as belligerents failed to respect international humanitarian law, attacked aid personnel, blocked relief convoys, manipulated food aid, and "taxed" humanitarians. In Liberia, for instance, warlord Charles Taylor demanded $15 \%$ of aid entering territory that he controlled. Estimates of the percentage of aid looted, 
diverted, and extorted in Somalia reach as high as $80 \%$, while at least half of all food aid in the former Yugoslavia was used to feed and supply combatants. ${ }^{47}$

Aid diversion empowers those responsible for the bloodshed, while feeding killers in militarized camps not only threatens civilians but also enables violence. Paying a "tax" to those who control access allows humanitarians to assist victims but simultaneously funds continued violence by belligerents. Moreover, by working with spoilers-those not interested in peace-humanitarian organizations may grant legitimacy to otherwise illegitimate actors. Formal relations with spoilers implicitly acknowledge the latter's authority, and a relief role bolsters spoilers' claims of legitimacy.

In this context, humanitarians confront formidable dilemmas because their traditional operating principles frequently lead to unwanted outcomes. Observers have pointed to a major break in the late 1980s and early 1990s and describe the experiments on the increasingly complex terrain as "new humanitarianism" and "political humanitarianism." 48

Unintended negative consequences meant that reciting the humanitarian mantra was of no avail. The principles worked well as guidelines when combatants were from state militaries and usually respected the laws of war and humanitarian space. In the wake of the Rwandan genocide, however, even the best intentioned of efforts produced unanticipated and pernicious results. What economists call "negative externalities"especially striking was strengthening the position of the génocidaires who controlled the camps in Zaïre-were not the result of minor design flaws or a modest lack of professionalism.

Humanitarian principles are supposed to be insulated from politics, but there has been a growing recognition that humanitarian activities have political consequences and inextricably are part of politics. However, what was once implicitly political is now explicitly so, and what was once taken for granted is now problematized. Furthermore, agencies actually find these principles dysfunctional in some war-torn areas. In particular, access to populations in zones of violence often requires working alongside and associating their activities with those of militaries. As humanitarians have attempted to promote human rights, they have found that neutrality can be an obstacle. Can one be neutral toward war criminals? Humanitarian organizations, which once treated "politics" as a dirty word, have become more willing to engage with politics.

Alongside the formidable problems of war-torn societies, states were weakening or collapsing in the late 1980s and early 1990s, and outside agencies became the main lifeline for many distressed populations. Once a state ceases to maintain political authority or to have a monopoly on violence, borders lose meaning as the locus of war. The legality as well as the actuality of access are in doubt and may have little or nothing to do with the authorities that occupy central government offices in the national capital, the usual interlocutors.

The focus of the new wars on people or resources more than on territory or formal boundaries creates distinct challenges for humanitarians responding to conflicts that cross borders while being based essentially on the consent of territorially defined belligerents. Finding victims, securing access to them, and delivering relief has led to the creation of humanitarian space in law and practice-that is, room to maneuver and help in providing protection and relief to war-ravaged populations. But humanitarian space was guaranteed by states (including belligerents), for interstate conflicts, by the Geneva Conventions. ${ }^{49}$ In most new wars, victims do not have 
this luxury. Belligerents often do not provide consent, allow for the passage of relief, or respect international agreements-they are often unaware of them and are not signatories.

Civilian humanitarians themselves have become targets of violence, as evident from the growing number of fatalities among aid workers in Afghanistan and Iraq. A review of aid workers killed in recent years attests to a disconcerting upswing: from 1992 to 2001, 204 UN civilian personnel were killed and more than 250 assaulted or robbed. ${ }^{50}$ Thirty-one aid workers were killed in Afghanistan over the course of 2005, up from twenty-four the previous year. ${ }^{51}$ While the degree to which aid workers are increasingly in harm's way must be placed in the context of their mushrooming numbers, ${ }^{52}$ attacks causing multiple deaths, such as those on UN and ICRC headquarters in Baghdad in late 2003 or on multiple members of such private groups as MSF in Afghanistan in 2004 and Action Contre la Faim in Sri Lanka in 2006, suggest that attacking aid workers has a high theatrical demonstration value. ${ }^{53}$

Thus, the dangers of the new wars have not simply considerably circumscribed access to war-affected populations; the humanitarian mantle no longer affords meaningful physical protection for aid workers.

\section{Contemporary Impediments to Human Protection}

In looking back over the last two decades, and especially in thinking about the next, we find that the essential challenges of humanitarian intervention to halt genocide are not normative but operational. What political realities stand in the way of making R2P a reality—of turning "here we go again" into a genuine "never again," the fervent battle cry that resulted from the Holocaust of World War II? While constraints are certainly not in short supply, five crucial ones are discussed here. ${ }^{54}$

\section{A Trojan Horse}

Students of history who recall the so-called humanitarian interventions of the nineteenth century will understand why the contemporary version encounters a substantial residue of visceral anti-colonialism in the Third World. Commercial and geopolitical calculations were cloaked in the language of humanitarian and religious motives, with an overlay of paternalism. As a result, the doctrine was discredited among countries gaining independence from colonial rule, and something akin to this condemnation also can be seen as applying to the responsibility to protect.

Conditional sovereignty uncomfortably resurrects "standards of civilization" and "the white man's burden." 55 Powerful states can determine whose human rights justify departing from the principle of non-intervention. Most importantly, the responsibility to protect can seem a euphemism for US hegemony, the proverbial Trojan horse for imperial designs. Kofi Annan's plea that human rights transcend sovereignty met an outright rejection from many UN member states: "The use of force as a sanction for a breach of an international obligation may do more harm than the breach of the international obligation; the cure is often worse than the disease."

Readers should recall Kosovo, which highlighted the need for guidelines when nonintervention is morally repugnant but the Security Council is paralyzed. ${ }^{57}$ What nature and gravity of threats justify external military intervention? The ICISS proffered its response, but controversy continues over conflicting principles that produce normative incoherence, inconsistency, and contestation. ${ }^{58}$

Developing countries, at least in their collective public diplomacy, reaffirm the narrowest interpretation of traditional sovereignty. Algerian President Abdelaziz 
Bouteflika's remarks, after Annan's justification at the General Assembly in 1999, capture that position: "we remain extremely sensitive to any undermining of our sovereignty, not only because sovereignty is our last defence against the rules of an unequal world, but because we are not taking part in the decision-making process of the Security Council."59

The Non-Aligned Movement-with 113 members, arguably the most representative group of countries outside the UN itself-publicly rejects "the right of humanitarian intervention," even if Africans on their own usually are seeking more outside intervention to halt humanitarian disasters. ${ }^{60}$ Developing countries are not alone in their recalcitrance. For example, American "sovereigntists" have launched their own counterattack. ${ }^{61}$

David Rieff wonders whether the revolution of moral concern "has actually kept a single jackboot out of a single human face." ${ }^{\prime 2}$ My own somber lament is that there still is appallingly sparse responsibility to protect those suffering from atrocities that shock the human conscience- "unhumanitarian non-intervention." The reticence, and in some cases hostility, of many developing countries toward humanitarian intervention is unlikely to disappear as long as inconsistency and disingenuousness characterize Western responses to humanitarian catastrophes.

\section{9/11 and the Global War on Terrorism}

Conventional wisdom now holds that terrorism and the attacks on US territory of September 2001 brought a paradigm change in international relations. It has become equally commonplace to hear that the United Nations is at a crossroads. Speaking before the General Assembly in September 2003, the secretary-general stated that the world organization was at a "fork in the road... no less decisive than 1945 itself, when the United Nations was founded."63

The United Nations' credibility and legitimacy were the subjects of considerable debate well before 9/11. ${ }^{64}$ Selectivity and double standards in Security Council decisions about which conflicts warranted a response, for example, contributed to a sense that this UN organ was simply a conduit for Western security interests. Why persist in Bosnia and withdraw from Rwanda? Why commit so fully to Kosovo and not to Sudan or the DRC? Few would make the ideal the enemy of the good-that is, by insisting that humanitarian intervention must occur whenever and wherever a crisis exists or not at all. Nonetheless, too much and too blatant inconsistency tarnishes the UN's reputation as an honest broker.

Trumpeting self-defense as a response to 9/11 was understandable and even approved by the Security Council. However, the blanket authorization for Afghanistan can now be seen as a prelude to the Bush administration's determination to take on Iraq, with or without Security Council approval. In March 2003, the United Nations was sidelined in the war against Iraq. Everyone was unhappy-the UN could not impede US hegemony, nor could it approve the requisite action against Saddam Hussein.

Consensus building around R2P must be seen in this context. Many countries, in Europe and in the Third World, are unwilling to accept any use of military force that is not approved by the Security Council—not even for humanitarian or human-rights purposes, let alone for pre-emptive or preventive war. The authority of the international political process, however flawed, is at least regulated internationally. Setting aside agreed procedures, as NATO did in Kosovo and especially as Washington 
and London did in Iraq, threatens to destroy a tenuous but nonetheless essential rule governing international society. ${ }^{65}$

The wars in Iraq and on terror have had three stifling effects on necessary normative conversations about criteria in the General Assembly. ${ }^{66}$ First, the selective use of the Security Council has been compounded by the US/British decision to go to war against Iraq without Security Council approval after having so assiduously sought it. Indeed, this is a conversation stopper for many when considering setting aside the principle of non-intervention.

Second, the legitimate idea of humanitarian intervention has been contaminated by association with George W. Bush's and Tony Blair's spurious and largely ex post facto "humanitarian" justifications for invading Iraq. In a widely cited speech to his Sedgefield constituency in March 2004, Blair provided the clearest example of the potential for abusing R2P when applying it retroactively: "But we surely have a duty and a right to prevent the threat materialising; and we surely have a responsibility to act when a nation's people are subjected to a regime such as Saddam's."67

The 2002 National Security Strategy of the United States of America continues to circumscribe discussions about using force. ${ }^{68}$ The Bush doctrine "has had the effect of reinforcing fears both of US dominance and of the chaos that could ensue if what is sauce for the US goose were to become sauce for many other would-be interventionist ganders," according to Adam Roberts. ${ }^{69}$ How can one gainsay those who are reluctant to codify norms about using military force for human protection purposes? The Bush and Blair doctrine seems to require renewing the principle of non-intervention rather than any downgrading of sovereign prerogatives, even for a humanitarian rationale.

Third, the possibility of moving the General Assembly toward debating criteria has stalled. Ramesh Thakur argues that R2P criteria would make it more difficult for states to claim the humanitarian label for purely self-interested interventions. ${ }^{70}$ His logic is impeccable but irrelevant; this discussion has been postponed sine die in the General Assembly. The atmosphere has simply become too poisonous. Richard Falk explains why: "After September 11, the American approach to humanitarian intervention morphed into post hoc rationalizations for uses of force otherwise difficult to reconcile with international law."71

If R2P's "just cause threshold" could have justified humanitarian intervention in 1999 in Kosovo, would not the same logic apply to Saddam Hussein's regime, whose history was certainly as ugly as Slobodan Milosevic's? The just cause threshold could arguably have been invoked for Iraq, but it was not invoked before the resort to force and certainly was a minor factor in the decision to attack. Indeed, the just cause threshold might well have been invoked in March 1988-when Saddam used chemical weapons against the Kurdish city of Halabja in northern Iraq, instantly killing 5,000 civilians-or on numerous other occasions in the $1990 \mathrm{~s}$. But they were not. And in the run-up to the March 2003 war, only the most perfunctory of references were made. Thus, the use of "humanitarian" has the hollow ring of rationalization after the fact and after the earlier justifications-mainly WMDs and links to Al Qaeda-proved vacuous.

It is more doubtful still that the other criteria could have been satisfied: right intention, last resort, proportional means, reasonable prospects, and right authority. Moreover, the primary purpose of the war in Iraq was the pursuit of geopolitical interests; halting human suffering was at most an afterthought. There remains a question about whether reasonable non-military options had been exhausted and the means were proportional. Determining whether the consequences of the war are worse 
than inaction will require waiting to see how long the post-war misery lasts and the future shape of Iraq.

But, most important, even if the five previous criteria had been met, which clearly they were not, the ICISS emphasizes just authority, which preferably means an overwhelming show of support from the Security Council or at least from a regional organization. Dissent within the council about the war in Iraq, and indeed across the planet, was far more visible than in the case of Kosovo. In withdrawing the resolution to authorize military force in March 2003, Washington and London were not even assured a simple majority and were also confronting three vetoes. Moreover, there was not unanimous approval for the Iraq campaign from a nineteen-member regional body, as in Kosovo-in fact, both NATO and the European Union were split. And regional organizations were categorically against the war. Widespread international backing, let alone right authority, was conspicuously absent.

Military intervention for human protection purposes using The Responsibility to Protect is one thing; military intervention for preventive war is quite another. The world requires capabilities to come to the rescue of vulnerable peoples, not fuzzy applications of legitimate concepts to obfuscate more sinister motivations.

Countries that earlier would have supported the R2P concept subsequently became reluctant or hostile toward unilateral humanitarian intervention (that is, outside of Security Council decision making). As a result, "the Iraq war has undermined the standing of the United States and the U.K. as norm carriers... [and] the process of normative change is likely to be slowed or reversed."72 Widespread apprehensions regarding US military activism were rekindled by the Iraq crisis and confirmed by Blair's and Bush's attempts to twist the concept of the responsibility to protect.

In spite of incantations from Kofi Annan and his high-level panel, humanitarian intervention is a harder sell these days than a few years ago, thanks to fears about the use of any imprimatur. Humanitarian intervention is no longer on the side of the angels, for fear that the Bush administration could manipulate it and strengthen its rationale for pre-emptive attacks against rogue states and terrorists.

\section{The Distracted Superpower}

Terrorism, and UN responses to it, reveal and accentuate the implications of the postCold War international system based on US preponderance-military, economic, and cultural. While the members of the ICISS met in 2001 with French foreign minister Hubert Védrine, they failed to appreciate his apt depiction of hyper-puissance. On the one hand, major power politics have always dominated the UN. On the other hand, there is no modern precedent for the current dimensions of the US Goliath. UN diplomats almost unanimously described the debate surrounding the resolution withdrawn on the eve of the war in Iraq as "a referendum not on the means of disarming Iraq but on the American use of power."

What exactly is the meaning of a collective security organization in a world so dominated by a sole superpower? Washington is, at best, indifferent to the United Nations and, at worst, has a penchant to weaken or destroy it. Much of contemporary UN debate could be compared with the Roman Senate's efforts to control the emperor.

Washington's multilateral record in the twentieth century conveys "mixed messages," as Edward Luck reminds us. The United States has sometimes been the prime mover for international institutions and norms, but just as often it has kept its distance or stood in the way. ${ }^{74}$ In the past, Washington was careful and somewhat reluctant to thumb its nose openly. The argument was that American "exceptionalism" 
was, well, exceptional-that is, to be saved for an unusual set of events when international cooperation was simply out of the question.

The hard currency in the international system remains military might. Before the war on Iraq, the "hyper-power" was already spending more on its military than the next fifteen to twenty-five countries (depending on who was counting). With additional appropriations for Afghanistan and Iraq, Washington began spending more than the rest of the world's militaries combined. ${ }^{75}$ And even in the domain of soft power, the United States remains without challenge on the world stage for the foreseeable future, although some analysts see hegemony as more Western than American. ${ }^{76}$

Even so, downsizing of the armed forces over the last fifteen years means an insufficient supply of equipment and manpower to meet the demands for humanitarian intervention. There are bottlenecks in the US logistics chain-especially in airlift capacity-that make improbable a rapid international response to a fast-moving, Rwanda-like genocide. With half of the US Army tied down in Iraq and a quarter of its reserves overseas, questions are being raised about the capacity to adequately respond to a serious national security threat or a natural disaster like Hurricane Katrina, let alone "distractions" like Liberia or Haiti.

The prediction that major powers other than the United States would not respond with military force to a new humanitarian emergency after September 11 proved somewhat too pessimistic, as Europe's takeover from NATO of the Bosnia operation in December 2004 and other examples suggest. However, there is little doubt that US airlift capacity, military muscle, and technology are required for larger and longerterm deployments. For better or worse, the United States in the Security Council is what former US secretary of state Dean Rusk once called the fat boy in the canoe: "When we roll, everyone rolls with us."

The present is an unparalleled multilateral moment, with implications for humanitarian intervention to stop genocide as for other international decisions. There are two "world organizations." The United Nations is global in membership, but the United States is global in reach and power. UN-led or UN-approved operations with substantial military requirements take place only when Washington approves or at least acquiesces. The reality of US power means that if the United Nations and multilateral cooperation are to have a chance of working, let alone flourishing, the globe's remaining superpower must be on board. This undoubtedly will have to await the 2008 presidential election.

\section{War Economies, Spoilers, and Privatization}

Another crucial drag on the current international system's capacity to engage in humanitarian intervention is the nature of local war economies accompanied by spoilers and privatization. ${ }^{78}$ So called because they seek to prevent others from turning a page on armed conflict and thus to foster war, "spoilers"79 are perhaps better described as "war entrepreneurs"; these have been present in previous armed conflicts, but the current generation is more numerous and better equipped to wreak havoc. The synergy of local and global economic conditions, coupled with relatively inexpensive arms, allows nonstate actors to assemble military capacity without much difficulty or investment.

Laurent Kabila is reported to have quipped that all that was required to have an "army" in Zaïre was $\$ 10,000$ and a cell phone. Aid agencies and foreign militaries face a steep learning curve in negotiating or militarily securing access in such contexts. 
Reflection is more valuable than visceral reactions. Humanitarian impulses and goodwill simply are no longer adequate, if indeed they ever were. ${ }^{80}$

Two general types of economies circumscribe many contemporary wars and humanitarian action. First are "war economies," or those interests that directly profit from armed conflict. The new wars do not operate with the sophistication or technology of the US military-industrial complex, but a network of economically calculating actors profits from the production of violence. The second type is that of "aid economies," or interests that benefit from the provision of external assistance.

International efforts to thwart war economies follow two tracks: controlling means and controlling ends. The former seeks to prevent or limit economically based actors from developing their ability to wage war. Examples are international efforts to restrict the spread of small arms and regulations to ban mercenaries. ${ }^{81}$ The second track seeks to regulate the resources over which new wars are waged. The UN has emphasized the role of plundered natural resources, particularly in Africa. ${ }^{82}$ Natural resources used to be considered a blessing. But this truism has been called into question because a variety of resources-gold, silver, coltran, timber, copper, titanium, and diamonds-can be looted to sustain contemporary wars.

Powerful external commercial interests that are vital to national economic development-such as oil, mining, and timber companies-can sometimes constitute additional obstacles to relief efforts or even spark conflicts that trigger humanitarian crises. Foreign oil companies in Africa alone-the "scorched earth" of southern Sudan, the charged ethnic environment of the delta in Nigeria, or the deposits that have funded guerrillas and governments in Angola-demonstrate their significance.

The focus of predators in aid economies is not so much on benefiting from violence as on profiting from the generosity to relieve suffering. Aid can facilitate speculation, hoarding, and exploitation by greedy middlemen, and can generate conditions conducive to breeding future resentments and exacerbating local tensions. Furthermore, outside aid can also be a disincentive to indigenous capacity building.

Among humanitarians, the response to the new landscape has been a modified Hippocratic Oath-long a theme in the work of Mary Anderson-and the adoption of "do no harm" criteria. ${ }^{83}$ The idea is to carry out emergency efforts to improve the ability of communities and public authorities to take control of their own destinies, begin development, and react better to future disasters.

Although an in-depth analysis suggests that the economic impact of peacekeeping has been largely positive, aid operations "are regularly criticized for a wide array of damage they are thought to do to the war-torn economies into which they deploy." 84 The economies of war and of aid suggest the uncertain terrain on which aid workers tread while trying to help, and the complications are often especially acute after a military intervention. These elements were not unknown in earlier armed conflicts, but the magnitude of outside aid and a globalizing world economy create an unusual witch's brew in contemporary wars.

\section{A Humanitarian Identity Crisis}

For the last two decades, humanitarian agencies have careered from one emergency to another, confronting nearly unimaginable challenges. Some of these spectacles made front-page news and profiled heroic and not-so-heroic activities. In Bosnia, they attempted to provide relief to those trapped in so-called safe havens-zones, resembling prisons, that were supposed to protect inhabitants from Serbian attacks but in fact were among the most unsafe places on the planet. In Rwanda, 
humanitarians were largely absent during the genocide itself but began attempting to save millions of displaced peoples in camps militarized and controlled by the architects of the mass murder. In Kosovo, Afghanistan, and Iraq, aid-agency personnel were funded by and operated alongside invading and occupying soldiers, which meant that civilian helpers found themselves being treated as enemy combatants by insurgents. To add to their woes, aid agencies have been criticized as enriching themselves from the needs of local populations on the dole, requiring wars as part of a new international political economy. ${ }^{85}$

Twenty years of daunting challenges have compelled the members of the international humanitarian system to re-examine who they are, what they do, and how they do it. Questions that were once essentially answered, or were asked rhetorically with ready-made replies, are now open for honest debate. The most gut-wrenching recognition that well-intentioned humanitarian action can lead to negative consequences has forced humanitarian organizations to measure their effectiveness. Such exercises require contemplating not only the values that motivate actions but also the consequences of those actions.

The humanitarian enterprise is in considerable flux-if the industry were not a century and a half old, we might describe the present situation as a "mid-life crisis." The expiry date has passed for the international humanitarian system; what is driving the debate are differences over the value of military intervention. There is substantial disagreement about how humanitarian organizations should respond, with some insisting that they have to adapt and others arguing that adaptations might change humanitarianism beyond recognition. Indeed, while some suggest that the sector has improved its ability to deliver relief and protect rights, David Rieff contends that "humanitarianism [is] in crisis" because it has lost its soul by compromising with and conforming to the new world order. ${ }^{86}$

A philosophical chasm is widening about the political implications of humanitarian intervention and action. ${ }^{87}$ On one side are the "classicists," who continue to uphold the principles of neutrality, impartiality, and consent. On the other are "solidarists" who side with selected victims, publicly confront hostile governments, advocate partisan public policies in donor states, attempt to skew the distribution of aid resources, and refuse to respect the sovereignty of states. Moreover, many no longer view humanitarianism as limited to short-term emergency relief to war victims, because job descriptions now also include such broader objectives as protecting human rights, promoting democracy, fostering development, and hastening peace building. ${ }^{8}$

For many on the latter part of the spectrum, humanitarianism is no longer viewed as "pure," and acceptance of neutrality, a cornerstone of humanitarianism, is seen as naïve. Proponents believe that aid should not be merely palliative and given without regard to political context. Such a position is starkly apparent in the late Fred Cuny's labeling of Bosnian Muslims as "the well-fed dead," signaling the tragedy of aid workers' merely providing food assistance to those who were largely at risk not from starvation but from murder at the hands of Serbian troops and paramilitary forces. Rather, it should be ameliorative and address the structural problems that foment humanitarian crises in the first place. And, when possible, it should be conceived in such a way as to help cement peace processes.

An even more controversial cleavage appeared between classicists and solidarists with the advent of the most obviously politicized strain of humanitarianism, the use of military force to halt genocide. The spread of new wars and massive crises in Africa and the Balkans spawned a hot topic: whether or not the use of force could legitimately 
be advocated on humanitarian grounds, and, if so, whether its use did war victims more harm than good.

Since the 1990s, the goalposts have moved on numerous occasions. The explosion of new wars spurred rethinking about consent, impartiality, and neutrality, as well as the use of force. Some humanitarians espoused a more muscular stance and pushed for soldiers as "humanitarian warriors." At a minimum, most aid agencies took advantage of military action to secure humanitarian goals, but usually with a somewhat defensive and begrudging posture-as a last resort and for a limited time. However, as armed aid convoys and security for refugee camps became routine and insecurity remained, some humanitarians supported the use of force to militarily defeat those who cause or worsen crises.

At the other end of the spectrum, classicists still often view military forces as the antithesis of true humanitarianism, or at least as wishful thinking without the presence of substantial national interests to stay the course-which are rarely in evidence. These categories are designed to shed light on the nature of differences and do not necessarily portray the specific behavior of any agency at all times. What unites the classicists, however, is their worry about the "risk of being associated with a potentially unwelcome military force, and thereby losing the protective patina of neutrality." 89

The value of a humanitarian veneer for the military was obvious when Colin Powell described NGOs in Iraq as a "force multiplier." He was even clearer later in the same speech when he noted that they were part of his "combat team." 90 As one military analyst notes, "In the wake of 9/11 some Western countries, especially the United States, have stressed the strategic and force-protection benefits of assistance and reconstruction as part of broader military strategies."91

The new wars frame the peculiar collective-action problems of the new humanitarianisms, but they encounter a very old problem-the fragmentation of the international humanitarian system. With no central power of the purse and no wherewithal to ensure compliance, cohesive action in an atomized system is the exception rather than the rule. It is more necessary than ever with the growing number of NGOs, but it remains unlikely. Indeed, the word "system" disguises the fact that overall performance reflects the sum of individual actions rather than a planned, singular, and coherent whole. The use of another image, the international humanitarian "family," might be more apt in that it allows for several eventualities, including the extremely dysfunctional efforts of proprietary UN agencies and market-share-oriented NGOs. ${ }^{92}$

At the same time, it would be unfair to imply a total absence of adaptation. Humanitarian action has begun to evolve into a better-defined field of professional activity with improved and appropriate career development. Over the last two decades, what Larry Minear aptly calls the "humanitarian enterprise"93 has become a recognized field with more donors, deliverers, and regulators. Not only have the numbers grown, but also the field is characterized by regular interactions among the members; a greater reliance on specialized knowledge; and a collective awareness of a common undertaking, albeit with some old-timers protesting the fading of volunteerism and the onset of bureaucratization. ${ }^{94}$ Nothing could be more obvious than the need for professionalism among aid workers acting side-by-side with soldiers during humanitarian interventions.

However, collective-action problems are clearly exacerbated by the lack of agreement concerning the scope and nature of humanitarian activity. Some humanitarians 
pursue a broad range of tasks with military protection. Others, such as the ICRC, remain more closely committed to traditional principles, preferring not to be tainted by politicized activity that may endanger not only the fulfillment of goals but the lives of aid providers. Thus, in addition to the multiplicity of actors on the scene, an incentive structure that encourages resource grabbing, and donor preferences that may have geopolitical underpinnings, the humanitarian identity crisis is yet another centrifugal force pulling actors in multiple directions with respect to military intervention to halt genocide.

\section{Conclusion}

The ICISS was originally established because of the Security Council's failure to address dire humanitarian crises in Rwanda and Kosovo. However, the absence of meaningful military might in Rwanda-like the do-nothing approach in the Darfur region of Sudan, in Uganda, and in the DRC-represents a more serious threat to international order and justice than the council's paralysis in Kosovo.

A 1999 survey of affected populations in several war zones reports that fully two-thirds of civilians under siege who were interviewed by the ICRC in twelve war-torn societies wanted more intervention, and only $10 \%$ wanted none. ${ }^{95}$ A 2005 mapping exercise of operational contexts for humanitarian agencies finds that recipients, rightly, "are more concerned about what is provided than about who provides it." 96

It is soothing for those of us who are preoccupied with normative developments to point proudly to paragraphs 138-39 as one of the few success stories of the World Summit. On the one hand, that clearly is true. Cosmopolitanism is compelling normatively, and R2P is an important step. On the other hand, the summit has not altered the geopolitical reality that "never again" is an inaccurate description of the actual impact of the 1948 UNCG- "here we go again" is closer to the truth. There are limits to analysis and advocacy with neither the political will nor the operational capacity among major powers to act on new norms. Stephen Lewis is blunt: "Alas, man and woman cannot live by rhetoric alone." 97

We live in a new world for which the International Commission on Intervention and State Sovereignty has reiterated the central role of the Security Council-reformed and enlarged or not-and urged it to act. But if it does not, humanitarians and victims are left where Kofi Annan was in September 1999 when he asked the audience in the General Assembly about their reactions had there actually been a state, or a group of states, willing to act early in April 1994 in Rwanda without a Security Council imprimatur. "Should such a coalition have stood aside," he asked rhetorically, "and allowed the horror to unfold?"98

While answers remain equivocal in diplomatic circles, the answer from any of the 800,000 dead Rwandans-or the millions of murdered Sudanese, Ugandans, and Congolese-would have been a resounding "No."

\section{Notes}

1. Scott Straus, "Rwanda and Darfur: A Comparative Analysis," Genocide Studies and Prevention 1 (2006): 41-56.

2. David Kennedy, The Dark Sides of Virtue: Reassessing International Humanitarianism (Princeton, NJ: Princeton University Press, 2004).

3. Outcome Document of the 2005 World Summit, UN Doc. A/RES/60/1 (24 October 2005), paras. 138-39. 
4. Convention on the Prevention and Punishment of the Crime of Genocide, 9 December 1948, 78 U.N.T.S. 277.

5. International Commission on Intervention and State Sovereignty, The Responsibility to Protect (Ottawa: ICISS, 2001). Quotes are from the "Synopsis," xi-xiii.

6. See, e.g., Roberta Cohen and Francis M. Deng, Masses in Flight: The Global Crisis of Internal Displacement (Washington, DC: Brookings Institution, 1998); Roberta Cohen and Francis M. Deng, eds., The Forsaken People: Case Studies of the Internally Displaced (Washington, DC: Brookings Institution, 1998). For a historical overview, see Thomas G. Weiss and David A. Korn, Internal Displacement: Conceptualization and Its Consequences (London: Routledge, 2006).

7. See James Traub, The Best Intentions: Kofi Annan and the UN in the Era of American World Power (New York: Farrar, Straus and Giroux, 2006).

8. Kofi A. Annan, "Two Concepts of Sovereignty," The Economist, 18 September 1999, http://www.un.org/News/ossg/sg/stories/articleFull.asp?TID=33\&Type=Article (accessed 16 January 2007).

9. Five speeches from 1998 and 1999 are reproduced in Kofi A. Annan, The Question of Intervention: Statements by the Secretary-General (New York: United Nations, 1999). For a discussion of the September 1999 speech, see Thomas G. Weiss, "The Politics of Humanitarian Ideas," Security Dialogue 31, 1 (2000): 11-23.

10. Kofi A. Annan, "We the Peoples": The United Nations in the 21st Century (New York: United Nations, 2000).

11. Gareth Evans, Foreword to The United Nations, Peace and Security: From Collective Security to the Responsibility to Protect, by Ramesh Thakur, xi-xv (Cambridge: Cambridge University Press, 2006), xiv.

12. Michael Reisman, "Sovereignty and Human Rights in Contemporary International Law," American Journal of International Law 84 (1990): 866-76; Louis Henkin, "Kosovo and the Law of 'Humanitarian Intervention," American Journal of International Law 93 (1999): 824-28.

13. Responsibility to Protect, xi.

14. Ibid., xii.

15. Ibid.

16. See Michael Walzer, Just and Unjust Wars: A Moral Argument with Historical Illustrations, 3rd ed. (New York: Basic Books, 2000), including a revised discussion on humanitarian intervention, 101-8; J. Bryan Hehir, "Intervention: From Theories to Cases," Ethics and International Affairs 9 (1995): 1-13.

17. Chantal de Jonge Oudraat, Intervention in Internal Conflicts: Legal and Political Conundrums (Washington, DC: Carnegie Endowment for International Peace, 2000).

18. Responsibility to Protect, xii.

19. Ibid., xiii.

20. Independent International Commission on Kosovo, Kosovo Report: Conflict, International Response, Lessons Learned (Oxford: Oxford University Press, 2000), 4.

21. Simon Chesterman, Just War or Just Peace? Humanitarian Intervention and International Law (Oxford: Oxford University Press, 2003); Nicholas J. Wheeler, Saving Strangers: Humanitarian Intervention in International Society (Oxford: Oxford University Press, 2000).

22. Th. A. van Baarda, "The Involvement of the Security Council in Maintaining International Law," Netherlands Quarterly of Human Rights, 12 (1994): 137-52, 140.

23. Mohammed Ayoob, "Humanitarian Intervention and International Society," International Journal of Human Rights 6 (2002): 81-102, 84.

24. For a discussion see Thomas G. Weiss and Barbara Crossette, "The United Nations: Post-Summit Outlook," in Great Decisions 2006, 9-20 (New York: Foreign Policy Association, 2007). 
25. Alex J. Bellamy, "Whither the Responsibility to Protect? Humanitarian Intervention and the 2005 World Summit," Ethics and International Affairs 20 (2006): 143-69.

26. See Herbert Weiss and Tatiana Carayannis, "The Enduring Idea of the Congo," in Borders, Nationalism, and the African State, ed. Ricardo René Larémont, 135-77 (Boulder, CO: Lynne Rienner, 2005).

27. Office of the Spokesman for the Secretary-General, "Secretary-General's Remarks to the Security Council on the Democratic Republic of the Congo" (New York, 1 October 2004), http://www.un.org/apps/sg/sgstats.asp?nid=1108 (accessed 8 January 2007).

28. International Rescue Committee, "The Congo Crisis at a Glance: The Forgotten Emergency" (IRC, n.d.), http://www.theirc.org/what/page.jsp?itemID=27814363 (accessed 8 January 2007).

29. Olara A. Otunnu, “The Secret Genocide,” Foreign Policy, July/August 2006, 45-46.

30. Ibid., 45, 46.

31. Samantha Power, "A Problem from Hell": America and the Age of Genocide (New York: Basic Books, 2001).

32. Nicholas D. Kristof, "Genocide in Slow Motion," New York Review of Books, 9 February 2006, 14. See Julie Flint and Alex de Waal, A Short History of a Long War (London: Zed Books, 2005); Gérard Prunier, Darfur: The Ambiguous Genocide (Ithaca, NY: Cornell University Press, 2005); "Genocide in Darfur," special issue, Genocide Studies and Prevention 1 (2006).

33. UN OCHA, "Sudan: US Congress Unanimously Defines Darfur Violence as 'Genocide," 23 July 2004, http://www.globalsecurity.org/military/library/news/2004/07/mil-040723irin03.htm (accessed 8 January 2007).

34. Colin Powell, "The Crisis in Darfur" (written remarks before the Senate Foreign Relations Committee, 9 September 2004), http://www.state.gov/secretary/former/powell/remarks/ 36032.htm (accessed 8 January 2007).

35. Physicians for Human Rights, "Call for Intervention to Save Lives in the Sudan: Field Team Compiles Indicators of Genocide," 23 June 2004, http://www.harvardhumanitarian. org/articles/sudan_genocide_report.pdf (accessed 17 January 2007).

36. "EU Lawmakers Call Darfur 'Crisis Genocide," Agence France Presse, 16 September 2004, http://www.middle-east-online.com/english/sudan/?id=11287 (accessed 17 January 2007).

37. See William G. O'Neill and Violette Cassis, Protecting Two Million Internally Displaced: The Successes and Shortcomings of the African Union in Darfur (Washington, DC: Brookings Institution-University of Bern Project on Internal Displacement, 2005).

38. "U.N. Humanitarian Official Says Darfur Crisis Is at Crucial Moment," New York Times, 19 November 2006.

39. David Rieff, "A Nation of Pre-emptors?” New York Times Magazine, 15 January 2006, 12.

40. Thomas G. Weiss and Don Hubert, The Responsibility to Protect: Research, Bibliography, Background (Ottawa: ICISS, 2001), ch. 8.

41. Victoria K. Holt and Tobias C. Berkman, The Impossible Mandate? Military Preparedness, the Responsibility to Protect and Modern Peace Operations (Washington, DC: Henry L. Stimson Center, 2007), 13.

42. Jean Pictet, The Fundamental Principles of the Red Cross (Geneva: Henry Dunant Institute, 1979). See David Forsythe, The Humanitarians: The International Committee of the Red Cross (Cambridge: Cambridge University Press, 2005).

43. Peter J. Hoffman and Thomas G. Weiss examine these topics in Sword \& Salve: Confronting New Wars and Humanitarian Crises (Lanham, MD: Rowman \& Littlefield, 2006), ch. 2. See also Michael Barnett and Thomas G. Weiss, eds., Humanitarianism in Question: Politics, Power, Ethics (Ithaca, NY: Cornell University Press, 2007).

44. See François Bugnion, The International Committee of the Red Cross and the Protection of War Victims (Geneva: ICRC, 2003), ch. 2. 
45. Hugo Slim, "Protecting Civilians: Putting the Individual at the Humanitarian Centre," in The Humanitarian Decade: Challenges for Humanitarian Assistance in the Last Decade and into the Future, Vol. II, ed. Office of the Coordinator of Humanitarian Assistance, 154-69 (New York: United Nations, 2004).

46. Mark Duffield, Global Governance and the New Wars: The Merging of Development and Security (London: Zed Books, 2001), 12. See also Philip White, "Complex Political Emergencies: Grasping Contexts, Seizing Opportunities," Disasters 24 (2000): 288-90.

47. Fiona Terry, Condemned to Repeat? The Paradox of Humanitarian Action (Ithaca, NY: Cornell University Press, 2002), 39-40.

48. See Joanna Macrae, ed., The New Humanitarianisms: A Review of Trends in Global Humanitarian Action (London: Overseas Development Institute, 2002).

49. Michael Bryans, Bruce D. Jones, and Janice Gross Stein, Mean Times: Humanitarian Action in Complex Political Emergencies-Stark Choices, Cruel Dilemmas (Report of the NGOs in Complex Emergencies Project), Coming to Terms 1, 3 (January 1999), 9-10.

50. Cate Buchanan and Mireille Widmer, Putting Guns in Their Place: A Resource Pack for Two Years of Action by Humanitarian Agencies (London: Overseas Development Institute, 2004), 35.

51. Afghanistan Watch, "Afghanistan by the Numbers" (n.d.), http://www.tcf.org/afghanistanwatch/listserv1-18-06.htm\#1 (accessed 7 January 2007).

52. Abby Stoddard, Adele Harmer, and Katherine Haver, Providing Aid in Insecure Environments: Trends in Policy and Operations (HPG Report 23) (London: Overseas Development Institute, 2006), 1, 13.

53. See Laura Hammond, "The Power of Holding Humanitarianism Hostage and the Myth of Protective Principles," in Humanitarianism in Question: Politics, Power, Ethics, ed. Michael Barnett and Thomas G. Weiss (Ithaca, NY: Cornell University Press, forthcoming).

54. See Thomas G. Weiss, "The Responsibility to Protect in a Unipolar Era," Security Dialogue 35 (2004): 135-53.

55. See Ayoob, "Humanitarian Intervention"; and David Chandler, From Kosovo to Kabul: Human Rights and International Intervention (London: Pluto Press, 2002).

56. Michael Akehurst, "Humanitarian Intervention," in Intervention in World Politics, ed. Hedley Bull, 95-118 (Oxford: Clarendon Press, 1984), 111.

57. See Albrecht Schnabel and Ramesh Thakur, eds., Kosovo and the Challenge of Humanitarian Intervention: Selective Indignation, Collective Action, and International Citizenship (Tokyo: United Nations University Press, 2000).

58. See Ramesh Thakur, The United Nations, Peace and Security: From Collective Security to The Responsibility to Protect (Cambridge: Cambridge University Press, 2006), ch. 12.

59. Quoted by Kathleen Newland with Erin Patrick and Monette Zard, No Refuge: The Challenge of Internal Displacement (New York: UN Office for the Coordination of Humanitarian Assistance, 2003), 37.

60. Philip Nel, "South Africa: The Demand for Legitimate Multilateralism," in Kosovo and the Challenge of Humanitarian Intervention: Selective Indignation, Collective Action, and International Citizenship, ed. Albrecht Schnabel and Ramesh Thakur, 245-59 (Tokyo: United Nations University Press, 2000).

61. Peter J. Spiro, “The New Sovereigntists," Foreign Affairs 79, 6 (2000): 9-15.

62. David Rieff, A Bed for the Night: Humanitarianism in Crisis (New York: Simon \& Schuster, 2002), 11.

63. The Secretary-General's Address to the General Assembly, New York, 23 September 2003, http://www.un.org/webcast/ga/58/statements/sg2eng030923.htm (accessed 17 January 2007).

64. See Jane Boulden and Thomas G. Weiss, eds., Terrorism and the UN: Before and After September 11 (Bloomington: Indiana University Press, 2004); Thomas G. Weiss, Margaret E. Crahan, and John Goering, eds., Wars on Terrorism and Iraq: Human Rights, Unilateralism, and U.S. Foreign Policy (London: Routledge, 2004). 
65. For a readable account that takes into account developments after 9/11, see Michael Byers, War Law: Understanding International Law and Armed Conflict (New York: Grove Press, 2005).

66. See Thomas G. Weiss, "R2P after $9 / 11$ and after the World Summit," Wisconsin International Law Journal 24 (2006): 741-60.

67. "Speech Given by the Prime Minister in Sedgefield, Justifying Military Action in Iraq and Warning of the Continued Threat of Global Terrorism," Guardian Unlimited, 5 March 2004, http://politics.guardian.co.uk/iraq/story/0,12956,1162991,00.html (accessed 8 January 2007).

68. National Security Strategy of the United States of America, September 2002, http://www.whitehouse.gov/nsc/nss.html (accessed 17 January 2007).

69. Adam Roberts, "The United Nations and Humanitarian Intervention," in Humanitarian Intervention and International Relations, ed. Jennifer Welsh, 71-97 (Oxford: Oxford University Press, 2004), 90.

70. Ramesh Thakur, "In Defence of the Responsibility to Protect," International Journal of Human Rights 7 (2003): 197-215. See also Gareth Evans, "Uneasy Bedfellows: "The Responsibility to Protect' and Feinstein-Slaughter's 'Duty to Prevent"' (speech at the American Society of International Law Conference, Washington, DC, 1 April 2004), http://www.crisisweb.org/home/index.cfm?id=2560\&l=1 (accessed 8 January 2007).

71. Richard Falk, contribution to "Humanitarian Intervention: A Forum," The Nation, 14 July 2003, 12.

72. Alex J. Bellamy, "Responsibility to Protect or Trojan Horse? The Crisis in Darfur and Humanitarian Intervention after Iraq," Ethics and International Affairs 19 (2005): 31-53, 32-33.

73. James Traub, "The Next Resolution," New York Times Magazine, 13 April 2003, 51.

74. Edward C. Luck, Mixed Messages: American Politics and International Organization, 1919-1999 (Washington, DC: Brookings Institution Press, 1999).

75. "Last of the Big Time Spenders: U.S. Military Budget Still the World's Largest, and Growing" (Center for Defense Information, Table on "Fiscal Year 2004 Budget," based on data provided by the US Department of Defense and International Institute for Strategic Studies, Washington, DC), 19 March 2003, http://www.cdi.org/friendlyversion/ printversion.cfm?documentID=1040 (accessed 17 January 2007).

76. Donald J. Puchala, "World Hegemony and the United Nations," International Studies Review 7 (2005): 571-84.

77. Quoted by Lincoln Palmer Bloomfield, Accidental Encounters with History (and Some Lessons Learned) (Cohasset, MA: Hot House Press, 2005), 14.

78. See Thomas G. Weiss and Peter J. Hoffman, "Making Humanitarianism Work," in Making States Work: State Failure and the Crisis of Governance, ed. Simon Chesterman, Michael Ignatieff, and Ramesh Thakur, 296-317 (Tokyo: United Nations University Press, 2005).

79. See Stephen John Stedman, Donald S. Rothchild, and Elizabeth Cousens, eds., Ending Civil Wars: The Implementation of Peace Agreements (Boulder, CO: Lynne Rienner, 2002).

80. See Thomas G. Weiss, "The Humanitarian Impulse," in The UN Security Council: From the Cold War to the 21st Century, ed. David Malone, 37-54 (Boulder, CO: Lynne Rienner, 2004).

81. For a discussion see Keith Krause, "Multilateral Diplomacy, Norm Building, and UN Conferences: The Case of Small Arms and Light Weapons," Global Governance 8 (2002): 247-63.

82. United Nations, The Causes of Conflict and the Promotion of Durable Peace and Sustainable Development in Africa: Report of the UN Secretary General to the Security Council, UN Doc. A/52/871-S/1998/318, April 1998.

83. Mary B. Anderson, Do No Harm: How Aid Can Support Peace-or War (Boulder, CO: Lynne Rienner, 1999).

84. Michael Carnahan, William Durch, and Scott Gilmore, Economic Impact of Peacekeeping: Final Report (New York: UN Peacekeeping Best Practices Unit, 2006), iii. 
85. See Alex de Waal, Famine Crimes: Politics and the Disaster Relief Industry in Africa (Oxford: James Currey, 1997); Michael Maren, The Road to Hell: The Ravaging Effects of Foreign Aid and International Charity (New York: Free Press, 1997); Duffield, Global Governance; Mark Duffield, Aid Policy and Post-Modern Conflict: A Critical Review [Occasional paper 19] (Birmingham, UK: School of Public Policy, 1998).

86. David Rieff, "Humanitarianism in Crisis," Foreign Affairs 81, 6 (2002): 111-21.

87. See Thomas G. Weiss, "Principles, Politics, and Humanitarian Action," Ethics and International Affairs 13 (1999): 1-22.

88. Michael Barnett, "Humanitarianism Transformed," Perspectives on Politics 3 (2005): $723-41$.

89. Victoria Wheeler and Adele Hammer, Executive Summary of Resetting the Rules of Engagement: Trends and Issues in Military-Humanitarian Relations, HPG Report 21 (London: Overseas Development Institute, 2006), 2.

90. Colin L. Powell, "Remarks to the National Foreign Policy Conference for Leaders of Non-governmental Organizations," US Department of State, 26 October 2001.

91. Stuart Gordon, "The Changing Role of the Military in Assistance Strategies," in Resetting the Rules of Engagement: Trends and Issues in Military-Humanitarian Relations, HPG Report 21, ed. Victoria Wheeler and Adele Hammer, 39-52 (London: Overseas Development Institute, 2006), 39.

92. For the most recent proposals, see the Secretary-General's High-Level Panel on UN System-Wide Coherence in the Areas of Development, Humanitarian Assistance, and the Environment, Delivering as One (New York: United Nations, 2006), paras. 20-24.

93. Larry Minear, The Humanitarian Enterprise: Dilemmas and Discoveries (West Hartford, CT: Kumarian, 2002).

94. Stephen Hopgood, Keepers of the Flame: Understanding Amnesty International (Ithaca, NY: Cornell University Press, 2006).

95. Greenberg Research, The People on War Report (Geneva: ICRC, 1999), xvi.

96. Antonio Donini, Larry Minear, Ian Smillie, Ted van Baarda, and Anthony C. Welch, Mapping the Security Environment: Understanding the Perceptions of Local Communities, Peace Support Operations, and Assistance Agencies (Medford, MA: Feinstein International Famine Center, June 2005), 53.

97. Stephen Lewis, Race Against Time (Toronto: Anansi Press, 2005), 145.

98. Annan, The Question of Intervention, 39. 